\title{
PENGUASAAN KONSEP IPA DITINJAU DARI KONSEP DIRI DAN MINAT BELAJAR SISWA
}

\author{
LIN SUCIANI ASTUTI \\ Program Studi Teknik Informatika, Universitas Indraprasta PGRI \\ Email: elinsuciaja@gmail.com
}

\begin{abstract}
Abstrak. Tujuan penelitian ini untuk mengetahui pengaruh konsep diri dan minat belajar terhadap penguasaan konsep IPA. Instrumen yang digunakan dalam penelitian ini yaitu angket konsep diri dan minat belajar sedangkan pengukuran penguasaan konsep berdasarkan soa-soal IPA. Analisis data pengujian yang digunakan adalah Regresi Ganda. Hasil analisis data penelitian membuktikan bahwa:(1) terdapat pengaruh yang signifikan konsep diri dan minat belajar secara bersama-sama terhadap penguasaan konsep IPA, hal ini dibuktikan oleh nilai $\mathrm{F}_{\text {hitung }}=10,803>\mathrm{F}_{\text {tabel }}$ dan nilai $\mathrm{Sig}=0,000<0,05$; (2) terdapat pengaruh yang signifikan konsep diri terhadap penguasaan konsep IPA, hal inidiperlihatkan dari hasil perhitungan yang menunjukkan nilai $t_{\text {hitung }}=3.471$ dan sig $=$ 0,001 , lebih kecil dibandingkan 0,05. (3) Minat belajar memberikan pengaruh positif dan signifikan terhadap penguasaan konsep IPA. Hal ini diperlihatkan dari hasil perhitungan yang menunjukkan nilai $t_{\text {hitung }}=2,620$ dan sig $=0,010$, lebih kecil dibandingkan 0,05 . Walaupun jika dibandingkan dengan konsep diri, minat belajar nilai sig-nya lebih besar. Sehingga konsep diri lebih berpengaruh besar terhadap penguasaan konsep IPA daripada minat belajar.
\end{abstract}

Kata Kunci: Konsep Diri, Minat Belajar, Penguasaan Konsep IPA

\begin{abstract}
The purpose of this study to determine the effect of self-concept and interest in learning the mastery of science concepts. The instrument used in this study is a questionnaire self-concept and interest in learning while measuring mastery of concepts based on the soa-matter of IPA. Analysis of the test data used is Multiple Regression. Results of analysis of research data to prove that: (1) there is significant influence self concept and interest in learning together toward mastery of science concepts, this is evidenced by the value of $\mathrm{F}=10.803>$ Ftabel and the $\mathrm{Sig}=0.000<0.05$; (2) there is a significant influence on the concept of self-mastery of the concept of science, it is shown from the results of calculations which show the value $t=3,471$ and sig $=0,001$, lower than 0.05 . (3) Interest in learning gives positive and significant impact on the mastery of science concepts. This is shown from the results of calculations which show the value $\mathrm{t}=$ 2.620 and $\mathrm{sig}=0,010$, lower than 0.05. Although when compared to the self-concept, interest in learning the value of sig is larger. So the concept of self is a major influence on the mastery of science concepts of the interest in learning.
\end{abstract}

Keywords: Self-Concept, Interest in Learning, Concept Mastery IPA

\section{PENDAHULUAN}

Pendidikan menurut Kamus Besar Bahasa Indonesia ialah proses pengubahan sikap dan tingkah laku seseorang atau kelompok orang dalam usaha mendewasakan manusia melalui upaya pengajaran dan pelatihan.Pendidikan itu sendiri dapat dirumuskan dari sudut normatif karena menurut hakikatnya pendidikan memang sebagai suatu peristiwa yang memiliki norma, artinya bahwa dalam peristiwa pendidikan, pendidik dan anak didik berpegang pada ukuran norma hidup, pandangan terhadap individu dan masyarakat, nilai-nilai moral, dan kesusilaan. 
Pendidikan IPA menjadi suatu bidang ilmu yang memiliki tujuan agar setiap siswa terutama yang di SMP memiliki kepribadian yang baik dan dapat menerapkan sikap ilmiah serta dapat mengembangkan potensi yang ada di alam untuk dijadikan sebagai sumber ilmu dan dapat diterapkan dalam kehidupan sehari-hari.

Pemberian pendidikan IPA di sekolah menengah pertama bertujuan agar siswa paham dan menguasai konsep alam dengan baik. Pembelajaran ini juga bertujuan agar siswa dapat menggunakan metode ilmiah untuk menyelesaikan persoalan alam yang berhubungan dengan kehidupan sehari-hari.

Kenyataan yang terjadi di Indonesia, mata pelajaran IPA tidak begitu di minati dan kurang diperhatikan. Apalagi melihat kurangnya pendidikan yang menerapkan konsep IPA. Permasalahan ini terlihat pada cara pembelajaran IPA serta kurikulum yang diberlakukan tidak sesuai atau mempersulit pihak sekolah dan siswa, masalah yang dihadapi oleh pendidikan Ilmu Pengetahuan Alam sendiri berupa materi atau kurikulum, guru, fasilitas, peralatan siswa dan komunikasi antara siswa dan guru.

Sebagai penentu keberhasilan perkembangan kepribadian seorang siswa dalam proses belajar IPA adalah konsep diri dan keminatan belajar siswa. Konsep diri merupakan sifat yang unik pada manusia sehingga dapat digunakan untuk membedakan manusia dari makhluk hidup yang lainnya. Para ahli psikologi kepribadian berusaha menjelaskan sifat dan fungsi konsep diri sehingga terdapat beberapa pengertian. Konsep diri seseorang dinyatakan melalui sikap dirinya yang merupakan aktualisasi orang tersebut. Manusia sebagai organisme yang memiliki dorongan untuk berkembang, pada akhirnya menyebabkan ia sadar akan keberadaan dirinya. Perkembangan yang berlangsung tersebut kemudian membantu pembentukan konsep diri individuyang bersangkutan. Menurut Willian D. Brooks konsep diri adalah pandangan dan perasaan kita tentang diri kita (Rakhmat, 2005:105). Konsep diri tersebut dalam penilaian dirinya seseorang ada yang bernilai positif dan ada pula yang negatif. Konsep diri yang positif memungkinkan seorang siswa mempunyai minat yang tinggi terhadap pembelajaran yang pada akhirnya menghasilkan penguasaan konsep yang baik. Sebaliknya konsep diri yang negatif akan membuat siswa semakin menemui kegagalan dalam belajar. Dalam pembelajaran di sekolah diharapkan terbentuk konsep diri yang positif pada diri siswa melalui pembelajaran yang diberikan.

Pada kenyataannya, proses pembelajaran guru seringkali tidak di memperhatikan perkembangan konsep diri siswa, guru hanya menunaikan tugasnya sebagai pengajar, guru hanya menyampaikan materi pelajaran saja, tidak berusaha meningkatkan konsep diri yang positif pada siswa yang dapat memicu keberhasilan siswa untuk mencapai penguasaan konsep IPA yang maksimal.

Minat adalah suatu rasa lebih suka dan rasa ketertarikan pada suatu hal atau aktivitas, tanpa ada yang menyuruh.Upaya meningkatkan keberhasilan pembelajaran, proses pembelajaran IPA selalu menerapkan langkah-langkah ilmiah yang berupa metode ilmiah dalam melakukan eksperimen, yaitu melakukan observasi, eksperimen, penyusunan teori dan penyimpulan. Hal ini berarti siswa di tuntut untuk mandiri dalam belajar IPA, terutama ketika seorang siswa ingin membuktikan dan menguasai suatu konsep dari pembelajaran IPA.

Adanya sikap konsep diri dan minat dalam diri siswa untuk menguasai konsepkonsep IPA maka tujuan belajar akan berhasil di capai sebagaimana yang diharapkan. Minat tidak dibawa sejak lahir, melainkan diperoleh kemudian. Minat terhadap sesuatu dipelajari dan mempengaruhi belajar selanjutnya serta mempengaruhi penerimaan minatminat baru. Jadi minat terhadap sesuatu merupakan hasil belajar dan menyokong belajar selanjutnya. Walaupun minat terhadap sesuatu hal tidak merupakan hal yang hakiki untuk dapat mempelajari hal tersebut, asumsi umum menyatakan bahwa minat akan membantu 
seseorang mempelajarinya dan menemukan suatu kreativitas seseorang dalam jiwanya dengan apa yang sudah menjadi ketertarikannya.Berdasarkan fenomena yang telah di uraikan di atas, maka rumusan masalah penelitian ini adalah "1) Apakah terdapat pengaruh konsep diri dan minat belajar secara bersama-sama terhadap penguasaan konsep IPA siswa". Tujuan dari dilaksanakannya penelitian ini adalah Mengetahui dan menganalisis pengaruh konsep diri dan minat belajar terhadap penguasaan konsep belajar IPA siswa secara bersama-sama.

\section{TINJAUAN PUSTAKA}

Dalam upaya untuk mengoptimalisasi pemahaman konsep pada siswa adalah siswa harus berani mengungkapkan pendapatnya tentang materi yang disampaikan guru atau temannya. Ada tujuh ciri pemahaman konsep yaitu sebagai berikut.

1) Menyatakan ulang sebuah konsep

2) Mengklasifikasi obyek-obyek menurut sifat-sifat tertentu atau sesuai dengan konsepnya

3) Memberi contoh dan non contoh dari konsep

4) Menyajikan konsep dalam berbagai bentuk representasi matematis

5) Mengembangkan syarat perlu atau syarat cukup suatu konse

6) Menggunakan, memanfaatkan, dan memilih prosedur atau operasi tertentu

7) Mengaplikasikan konsep atau algoritma pemecahan masalah

Menurut Rosser dan Ratna Wilis Dahar(2006:63) "konsep adalah suatu abstraksi yang mewakili satu kelas obyek, kejadian, kegiatan, atau hubungan yang mempunyai atribut yang sama". Senada dengan Sagala (2005:71) "konsep merupakan buah pemikiran seseorang atau sekelompok orang yang dinyatakan dalam definisi sehingga melahirkan produk pengetahuan meliputi prinsip, hukum, dan teori”. Konsep diperoleh dari fakta, peristiwa, pengalaman melalui generalisasi dan berfikir abstrak, konsep dapat mengalami perubahan disesuaikan dengan fakta atau pengetahuan baru.

Konsep merupakan salah satu pengetahuan awal yang harus dimiliki siswa karena konsep merupakan dasar dalam merumuskan prinsip-prinsip. Menurut Dahar (1998:96) "konsep adalah suatu abstraksi yang memiliki suatu kelas objek-objek, kejadian-kejadian, kegiatan-kegiatan, hubungan-hubungan yang mempuyai atribut yang sama".Setiap konsep tidak berdiri sendiri melainkan berhubungan satu sama lain, oleh karena itu siswa dituntut tidak hanya menghafal konsep saja, tetapi hendaknya memperhatikan hubungan antara satu konsep dengan konsep yang lainnya.

Penguasaan konsep adalah kemampuan siswa dalam memahami konsep-konsep setelah kegiatan pembelajaran. Penguasaan konsep dapat diartikan sebagai kemampuan siswa dalam memahami makna secara ilmiah baik teori maupun penerapannya dalam kehidupan sehari-hari (Dahar, 2003:4). Sedangkan definisi penguasaan konsep yang lebih komprehensif dikemukakan oleh Bloom yaitu kemampuan menangkap pengertianpengertian seperti mampu mengungkapkan suatu materi yang disajikan ke dalam bentuk yang lebih dipahami, mampu memberikan interpretasi dan mampu mengaplikasikannya.

Dahar (2003:5) mendefinisikan penguasaan konsep sebagai kemampuan siswa dalam memahami makna secara ilmiah baik teori maupun penerapannya dalam kehidupan sehari-hari. Sedangkan definisi penguasaan konsep yang lebih komprehensif dikemukakan oleh Bloom (dalam Rustaman et al., 2005) yaitu kemampuan menangkap pengertian-pengertian seperti mampu mengungkapkan suatu materi yang disajikan ke dalam bentuk yang lebih dipahami, mampu memberikan interpretasi dan mampu mengaplikasikannya. Lebih lanjut, penguasaan konsep adalah kemampuan siswa yang bukan hanya sekedar memahami, tetapi juga dapat menerapkan konsep yang diberikan dalam memecahkan suatu permasalahan, bahkan untuk memahami konsep yang baru. 
Berdasarkan pendapat-pendapat tersebut dapat disimpulkan bahwa penguasaan konsep adalah kemampuan siswa dalam memahami makna pembelajaran dan mengaplikasikannya dalam kehidupan sehari-hari.

Indikator penguasaan konsep menurut Sumaya (2004:43) "yaitu seseorang dapat dikatakan menguasai suatu konsep jika orang tersebut benar-benar memahami konsep yang dipelajarinya sehingga mampu menjelaskan dengan menggunakan kata-kata sendiri sesuai dengan pengetahuan yang dimilikinya, tetapi tidak mengubah makna yang ada didalamnya".

Konsep diri merupakan salah satu hal terpenting yang dapat mempengaruhi kehidupan seseorang. Ada beberapa pengertian tentang konsep diri, diantaranya menurut Desmita (2009:164) menyatakan:“ konsep diri adalah gagasan tentang diri sendiri yang mencakup keyakinan, pandangan, dan penilaian seseorang terhadap dirinya sendiri. Konsep diri terdiri atas bagaimana seseorang merasa tentang dirinya sendiri menjadi manusia, dan bagaimana seseorang menginginkan dirinya sendiri menjadi manusia sebagaimana ia harapkan."

Konsep diri dalam bukunya Slameto, (2013:182) adalah "persepsi keseluruhan yang dimiliki seseorang mengenai dirinya sendiri “. Burns (1977:42) dalam bukunyamengatakan: "the self concept refers to the connection of attitudes and beliefs we hold about ourselves"

Apakah konsep diri mempengaruhi hasil pendidikan ataukah hasil pendidikan mempengaruhi konsep diri, masih sering ditanyakan. Studi-studi korelasi menunjukan hubungan positif yang besar antara prestasi siswa dengan hasil pengukuran konsep dirinya. Elizabeth B. Hurlock (1978:114) menerangkan minat merupakan sumber motivasi yang mendorong orang untuk melakukan apa yang mereka inginkan bila mereka bebas memilih. Bila mereka melihat bahwa sesuatu akan menguntungkan, mereka merasa berminat. Ini kemudian akan mendatangkan kepuasan. Bila kepuasan berkurang, minat pun berkurang.

Pengertian Minat belajar adalah suatu penerimaan akan suatu hubungan antara diri sendiri dengan sesuatu diluar diri. Seseorang memiliki minat terhadap subjek tertentu cenderung untuk memberikan perhatian yang lebih besar terhadap subjek tertentu (Djamarah, 2008: 154). Definisi Minat belajar dari bukunya Muhibbin Syah (2006:66) adalah kecenderungan dan kegairahan yang tinggi atau keinginan yang besar terhadap sesuatu yang ingin dicapai.

Hamalik (2001: 158) berpendapat bahwa minat (motivasi) adalah perubahan energi dalam diri (pribadi) seseorang yang ditandai dengan timbulnya perasaan dan reaksi untuk mencapai tujuan. Tanpa adanya tujuan, orang tidak akan berminat (motivasi) untuk berbuat sesuatu. Seorang siswa melakukan kegiatan belajar selalu mempunyai tujuan mengapa ia melakukan kegiatan belajar tersebut. Oleh karena itu, minat (motivasi) merupakan faktor penting dalam kegiatan belajar. Adanya minat (motivasi) diharapkan dapat memperoleh hasil yang memuaskan dalam setiap kegiatan.

Sardiman, (2004: 83) mengemukakan ciri-ciri seseorang yang memiliki minat (motivasi) tinggi yaitu berupa; (1) Tekun dalam menghadapi tugas (dapat bekerja terus menerus dalam waktu yang lama, tidak pernah berhenti sebelum selesai), (b) Ulet menghadapi kesulitan ridak (tidak lekas putus asa), (c) Menunjukkan minat terhadap bermacam-macam masalah, (d) Lebih senang bekerja mandiri, (e) Cepat bosan pada tugas-tugas yang rutin (hal-hal yang berifat mekanis, berulang-ulang begitu saja sehingga kurang kreatif), (f) Dapat mempertahankan pendapatnya (kalau sudah yankin akan sesuatu), (g) Tidak mudah melepaskan hal yang diyakini itu, dan (h) Senang mencari dan memecahkan masalah soal-soal. 
Tingkah laku siswa ketika mengikuti proses belajar mengajar dapat mengindikasikan akan ketertarikan siswa tersebut terhadap pelajaran itu atau sebaliknya, ia merasa tidak tertarik dengan pelajaran tersebut. Ketertarikan siswa inilah yang merupakan salah satu tanda-tanda minat belajar.

Fungsi minat dalam belajar lebih besar sebagai motivating force yaitu sebagai kekuatan yang mendorong siswa untuk belajar. Siswa yang berminat kepada pelajaran akan tampak terdorong terus untuk tekun belajar, berbeda dengan siswa yang sikapnya hanya menerima pelajaran. mereka hanya tergerak untuk mau belajar tetapi sulit untuk terus tekun karena tidak ada pendorongnya. Oleh sebab itu untuk memperoleh hasil yang baik dalam belajar seorang siswa harus mempunyai minat terhadap pelajaran sehingga akan mendorong ia untuk terus belajar.Indikator Minat Belajar adalah:a) Perasaan Senang, b) Perhatian dalam Belajar, c) Bahan Pelajaran dan Sikap Guru yang Menarik, d) Manfaat dan Fungsi Mata Pelajaran.

\section{METODE}

Seluruh peserta didik kelas VII di SMP Negeri 3, SMP Negeri 11, dan SMP Negeri 24 Kota Tangerang,yang berjumlah 520 orang. SMP Negeri 3 kotaTangerang 300 orang, SMPNegeri 11 Tangerang kota340 orang dan SMP Negeri 24 kota Tangerang 320 orang. Jumlah sample yang diambil pada penelitian ini tergantung dari jumlah populasi dengan menggunakan rumus Taro Yamane: $\quad \mathrm{n}=\frac{N}{N \mathrm{~d}^{2}+1}$ jadi $\mathrm{n}=\frac{960}{960(0,1)^{2}+1}=90,56=90$ (dibulatkan)

Metode yang digunakan dalam penelitian ini adalah metode survey dan menggunakan teknik sampling proporsional Cluster Random sampling, dimana jumlah sample dari setiap sekolah diambil secara proporsional berdasarkan perbandingan jumlah siswa setiap sekolah terhadap jumlah populasi keseluruhan. Dengan teknik ini maka diperoleh sampel dari masing-masing sekolah sebagai berikut;

a. SMP Negeri 3 Tangerang $=\frac{300}{960} \times 90=28,125=28$ (dibulatkan)

b. SMP Negeri 11 Tangerang $=\frac{340}{960} \times 90=31,875=32$ (dibulatkan)

c. SMP Negeri 24 Tangerang $=\frac{320}{960} \times 90=30$

\section{Analisis Statistik Deskriptif}

\section{Uji Normalitas Data}

Nilai $\mathrm{L}_{0}$ diperoleh dari rumus liliefors berikut: $z i=\frac{x i-x}{s i}$

\section{Uji Linearitas}

Untuk perhitungan uji linearitas pada penelitian menggunakan uji Anova dengan bantuan program spss versi 20 dengan criteria jika sig linearity $<0,05$ maka data tersebut berpola linear.

\section{Uji Multikolinearitas}

Untuk mendeteksi ada atau tidaknya multikolinearitas, dilakukan dengan melihat nilai tolerance dan Variance Inflation Factor $(\mathrm{VIF}) \geq 1$ atau korelasi antara $X_{1}$ dan $X_{2}>0,5$. ( Santoso, 2005: 204)

\section{Teknik Pegujian Hipotesis}

Uji hipotesis dilakukan dengan menggunakan analisis regresi ganda pada taraf signifikan $\alpha=0,05$. Perhitungan analisis regresi linier berganda ini dengan menggunaka persamaan sebagai berikut:

$$
\hat{\mathbf{Y}}=\mathbf{a}_{0}+\mathbf{b}_{1} \mathbf{X}_{1}+\mathbf{b}_{2} \mathbf{X}_{2}
$$




\section{Pengujian Uji F}

Untuk menentukan harga $\mathrm{F}_{\text {hitung, yaitu: } F_{h}=\frac{R J K \text { reg }}{R J K \text { res }}}$

Atau dapat dihitung langsung:

$$
F_{h}=\frac{R J K \text { reg }}{\text { RJK res }}=\frac{(J \text { Kreg }) / k}{(\text { RJKres }) /(n-k-1)}
$$

\section{HASIL DAN PEMBAHASAN}

Hasil perhitungannya uji $\mathrm{F}$ dapat ditunjukkan melalui tabel berikut.

Tabel 1. Model Summary: R, dan R Squared (Koefesien Penentu) Model Summary

\begin{tabular}{lllll}
\hline Model & R & R Square & $\begin{array}{l}\text { Adjusted } \\
\text { R Square }\end{array}$ & $\begin{array}{l}\text { Std. } \\
\text { Error of } \\
\text { the }\end{array}$ \\
& & & & $\begin{array}{l}\text { Estimate } \\
1\end{array}$ \\
\hline
\end{tabular}

Predictors: (Constant), minat belajar, konsep diri

Tabel 2. Koefesien Regresi dan Uji Signifikansi secara Parsial

\begin{tabular}{llllll}
\hline Model & Sum of Squares & df & Mean Square & $F$ & Sig. \\
\hline Regression & 1638.922 & 2 & 819.461 & 10.803 & $.000^{\mathrm{b}}$ \\
Residual & 6599.300 & 87 & 75.854 & & \\
Total & 8238.222 & 89 & & & \\
\hline a. Dependent Variable: penguasaan konsep IPA & \\
b. Predictors: (Constant), minat belajar, konsep diri &
\end{tabular}

Tabel 3. Koefisien Regresi dan Uji Signifikansi secara Parsial

\begin{tabular}{|c|c|c|c|c|c|c|}
\hline \multicolumn{7}{|c|}{ Coefficients $^{\mathrm{a}}$} \\
\hline & & \multicolumn{2}{|c|}{ Unstandardized Coefficients } & Standardized & $\mathrm{T}$ & Sig. \\
\hline & & B & Std. Error & Beta & & \\
\hline & (Constant) & 21.268 & 10.888 & & 1.953 & .054 \\
\hline \multirow[t]{2}{*}{1} & konsep diri & .270 & .078 & .336 & 3.471 & .001 \\
\hline & minat belajar & .196 & .075 & .254 & 2.620 & .010 \\
\hline \multicolumn{7}{|c|}{ a. Dependent Variable: penguasaan konsep IPA } \\
\hline
\end{tabular}

\section{Pembahasan}

Pengaruh Konsep Diri $\left(X_{1}\right)$, dan Minat Belajar $\left(X_{2}\right)$ secara bersama-sama terhadap Penguasaan Konsep IPA (Y)

Hipotesis pengaruh ini adalah:

$\mathrm{H}_{0}: \beta_{\mathrm{y} 1}=\beta_{\mathrm{y} 2}=0$

$\mathrm{H}_{1}: \beta_{\mathrm{y} 1} \neq 0$ atau $\beta_{\mathrm{y} 2} \neq 0$; 
Artinya:

$\mathrm{H}_{0}$ : tidak terdapat pengaruh konsep diri $\left(\mathrm{X}_{1}\right)$, dan minat belajar $\left(\mathrm{X}_{2}\right)$ secara bersamasama terhadap penguasaan konsep IPA (Y)

$\mathrm{H}_{1}$ : terdapat pengaruh konsep diri $\left(\mathrm{X}_{1}\right)$, dan minat belajar $\left(\mathrm{X}_{2}\right)$ secara bersama-sama terhadap penguasaan konsep IPA (Y)

Perhitungan pengujian signifikansi koefesien korelasi ganda tersebut diperoleh bahwa koefesien korelasi tersebut signifikan, dengan nilai $\mathrm{R}=+0,446$ yang berarti sedang. Sedangkan koefesien determinasinya sebesar 19,91 \% menunjukkan bahwa besarnya kontribusi konsep diri dan minat belajar secara bersama-sama terhadap penguasaan konsep IPA adalah sebesar 19,91\%, sisanya (80,01\%) karena faktor lain.

Berdasarkan angka-angka statistik pada tabel 3. menunjukkan bahwa nilai $F_{o}$ $=10.803$ dan sig $=0,000<0,05$. Hal ini menunjukkan bahwa $\mathrm{H}_{0}$ tidak dapat diterima, berarti $\mathrm{H}_{1}$ diterima. Artinya hipotesis penelitian dapat diterima. Artinya, terdapat pengaruh yang signifikan konsep diri dan minat belajar secara bersama-sama terhadap penguasaan konsep IPA.Berdasarkan persamaan regresi dapat dinarasikan sebagai berikut. Setiap kenaikan satu unit total skor konsep diri $\left(\mathrm{X}_{1}\right)$ akan berpengaruh kepada kenaikan penguasaan konsep IPA (Y) sebesar 0,270 unit total skor penguasaan konsep. Artinya variabel minat belajar $\left(\mathrm{X}_{2}\right)$ tetap tidak berubah. Hal yang sama juga, setiap kenaikan satu unit total skor minat belajar $\left(\mathrm{X}_{2}\right)$ akan berpengaruh kepada kenaikan penguasaan konsep IPA (Y) sebesar 0,196 unit total skore penguasaan konsep, ceteris paribus. Artinya variabel konsep diri $\left(\mathrm{X}_{1}\right)$ tetap tidak berubah. Disini tidak dapat secara langsung dinyatakan bahwa pengaruh konsep diri lebih tinggi dibandingkan dengan pengaruh minat belajar $\left(\mathrm{X}_{2}\right)$, walaupun nilai $\mathrm{B}$ variabel $\mathrm{X}_{1}$ lebih besar dibandingkan dengan nilai $\mathrm{B}$ pada variabel $\mathrm{X}_{2}$.

\section{Pengaruh Konsep Diri $\left(\mathrm{X}_{1}\right)$ terhadap Penguasaan Konsep IPA (Y)}

Hipotesis pengaruh ini adalah:

$\mathrm{H}_{0}: \beta_{\mathrm{y} 1}=0$

$\mathrm{H}_{1}: \beta_{\mathrm{y} 1} \neq 0$

Artinya:

$\mathrm{H}_{0}$ : tidak terdapat pengaruh konsep diri $\left(\mathrm{X}_{1}\right)$, terhadap penguasaan konsep IPA ( $\mathrm{Y}$ )

$\mathrm{H}_{1}$ : terdapat pengaruh konsep diri $\left(\mathrm{X}_{1}\right)$, terhadap penguasaan konsep IPA (Y).

Berdasarkan angka-angka statistik pada tabel 3. menunjukkan bahwa nilai $\mathrm{t}_{\mathrm{o}}=$ 3,471 dan sig $=0,001<0,05$. Hal ini menunjukkan bahwa $\mathrm{H}_{0}$ tidak dapat diterima, berarti $\mathrm{H}_{1}$ diterima. Artinya hipotesis penelitian dapat diterima. Artinya, terdapat pengaruh yang signifikan konsep diri terhadap penguasaan konsep IPA. Hal ini sesuai dengan data skor konsep diri yang mempunyai skor konsep diri positif tinggi maka nilai dari penguasaan konsep IPA pun tinggi sehingga variabel konsep diri $\left(\mathrm{X}_{1}\right)$ dengan variabel penguasaan konsep IPA (Y) terdapat data yang Linier. Data tersebut dibuktikan dengan uji linieritas dengan nilai sig. Deviation from Linearity memiliki $0,600>0,05$.

\section{Pengaruh Minat Belajar $\left(\mathrm{X}_{2}\right)$ terhadap Penguasaan Konsep IPA (Y)}

Hipotesis pengaruh ini adalah:

$\mathrm{H}_{0}: \beta_{\mathrm{y} 2}=0$

$\mathrm{H}_{1}: \beta_{\mathrm{y} 2} \neq 0$ 
Artinya:

$\mathrm{H}_{0}$ : tidak terdapat pengaruh minat belajar $\left(\mathrm{X}_{2}\right)$, terhadap penguasaan konsep IPA (Y)

$\mathrm{H}_{1}$ : terdapat pengaruh minat belajar $\left(\mathrm{X}_{2}\right)$, terhadap penguasaan konsep IPA (Y)

Berdasarkan angka-angka statistik pada tabel 4.9 menunjukkan bahwa nilai $\mathrm{t}_{\mathrm{o}}=$ 2,620 dan sig $=0,010<0,05$. Hal ini menunjukkan bahwa $\mathrm{H}_{0}$ tidak dapat diterima, berarti $\mathrm{H}_{1}$ diterima. Artinya hipotesis penelitian dapat diterima. Artinya, terdapat pengaruh yang signifikan minat belajar terhadap penguasaan konsep IPA. Hal ini dapat di buktikan dengan nilai $t_{0}=2,620$ dan sig $=0,010<0,05$.

\section{PENUTUP}

\section{Simpulan}

Berdasarkan deskripsi data penelitian dan setelah dilakukan analiisis data maka dapat disimpulkan:

1. Terdapat pengaruh yang signifikan konsep diri dan minat belajar secara bersamasamaterhadap penguasaan konsep IPA, siswa SMP Negeri di Kota Tangerang. Hal ini di buktikan dengan hasil nilai sig $=0,000<0,05$ dan $F_{\text {hitung }}=10,803$. Sehingga dapat disimpulkan semakin baik konsep diri dan minat belajar maka semakin terkuasai juga konsep-konsep IPA dan hasil belajarnya pun selalu maksimal.

2. Terdapat pengaruh yang signifikan konsep diri terhadap penguasaan konsep IPA, siswa SMP Negeri di Kota Tangerang. Hal ini dibuktikian dengan hasil perhitungan yang menunjukkan nilai sig $=0,001,<0,05$ dan $t_{\text {hitung }}=3.471$.

3. Terdapat pengaruh yang signifikan minat belajar terhadap penguasaan konsep IPA, siswa SMP Negeri di Kota Tangerang. Hal ini dibuktikan dengan hasil nilai sig = $0,010<0,05$ dan $t_{\text {hitung }}=2,620$. Walaupun jika dibandingkan dengan konsep diri, minat belajar nilai sig-nya lebih besar. Sehingga konsep diri lebih berpengaruh besar terhadap penguasaan konsep IPA daripada minat belajar.

\section{Implikasi}

Mengacu pada hasil-hasil penelitian sebagaimana yang diungkapkan diatas, maka implikasi dari hasil-hasil tersebut diuraikan berikut ini.

1. Upaya meningkatkan penguasaan konsep IPA melalui Konsep Diri dan Minat Belajar

Di upayakan siswa mampu mengonsep keadaan dirinya yang positif mulai dari hal terkecil baik dilakukan di rumah ataupun disekolah. Selain konsep diri yang positif sebagai anak pelajar yang baik, minat belajar pun harus tinggi terhadap semua mata pelajaran khususnya mata pelajaran IPA baik di dukung dari guru, orangtua, ataupun teman-temmannya, karena telah dibuktikan pada penelitian ini bahwa konsep diri yang positif dan minat belajar yang tinggi terhadap hasil belajar IPA dapat meningkat signifikan.

2. Upaya meningkatkan penguasaan konsep IPA melalui Konsep Diri

Siswa diharapkan memiliki konsep diri yang positif agar dapat memikirkan hal-hal yang bersifat konkret dan abstrak pada mata pelajaran IPA, seperti menyusun ideide, sistematik, dan berpikir apa yang terjadi kemudian. Dengan konsep diri tersebut siswa diharapkan memahami fakta, konsep, prinsip, maupun teori-teori pada pelajaran IPA sehingga siswa tidak mengalami kesulitan dalam menguasai konsepkonsep IPA.

3. Upaya meningkatkan penguasaan konsep IPA melalui minat belajar

Para guru hendaknya membangkitkan minat dengan memberikan beberapa motivasi pada setiap pelajaran, motivasi yang dapat dilakukan yaitu bisa dengan memberikan 
reward atau mengonsep belajar IPA diiringi dengan menyanyi sehingga akan terciptalah minat. Karena dari hasil penelitian ini siswa yang mempunyai minat belajar yang tinggi mampu menguasai konsep-konsep IPA dengan baik.

\section{Saran}

Berdasarkan hasil penelitian dan pembahasan serta simpulan di atas, dapat diberikan beberapa saran sebagai berikut:

1. Guru hendaknya menciptakan suasana belajar yang menyenangkan supaya dapat membangkitkan minat siswa dan rasa percaya diri agar tercipta konsep diri yang positif.

2. Penggunaan media pengajaran dalam pembelajaran salah satu sarana dalam membangkitkan minat dan motivasi dan harus disesuaikan dengan tujuan yang ingin dicapai dalam pembelajaran.

3. Dengan adanya berbagai keterbatasan dalam penelitian ini, maka diharapkan adanya penelitian lebih lanjut lagi untuk mengetahui apakah pembelajaran yang di dasari dengan konsep diri positif dan minat belajar yang tinggi dapat memberikan hasil yang lebih baik lagi dalam setiap mata pelajaran yang berbeda pada setiap jenjang pendidikan sehingga penguasaan konsep pada mata pelaran tersebut dapat terkuasai.

4. Diharapkan penelitian ini dapat menambah hasanah perpustakaan dan menjadi rujukan para peneliti lain. Sedangkan untuk pihak sekolah dapat memperhatikan dan mempergunakan penelitian ini sebagai bahan masukan dalam pembelajaran.

\section{DAFTAR PUSTAKA}

Dahar, R. 2006. Strategi Pembelajaran.Bandung: PT. Remaja Rosdakarya.

Desmita. 2009. Psikologi Perkembangan Peserta Didik. Bandung: PT Remaja Rosda Karya.

Hamalik, Oemar. 2001. Proses Belajar Mengajar. Jakarta: Bumi Aksara. Hurlock, Elizabeth B. 1998. Psikologi Perkembangan Anak. Jakarta:Erlangga.

Rusman, 2010. Model-Model Pembelajaran. Depok: Raja Grafindo Persada.

Sanada dan Sagala. 2005. Konsep dan Makna Pembelajaran. Bandung: CV. Alfabeta.

Sardiman A.M. 2007. Interaksi dan Motivasi Belajar Mengajar. Jakarta:Raja Grafindo.

Slameto. 2013. Belajar dan Faktor-Faktor Yang Mempengaruhi.Jakarta:Rineka Cipta. Syah, Muhibbin. 2002. Psikologi Pendidikan dengan Pendidikan Baru. Bandung: PT Remaja Rosdakarya.

Wuryani, Sri Estuti. 2002. Psikologi Pendidikan. Jakarta: PT Gramedia Widiasarana. 